\title{
Mycoplasma-like Organisms \\ Associated with Chat Fruit and Rubbery Wood Diseases of Apple, Malus domestica Borkh., Compared with Those in Strawberry with Green Petal Disease
}

\author{
By A. BER YL BEAKBANE, M. D. MISHRA,* \\ A. F. POSNETTE AND C. H. W. SLATER \\ East Malling Research Station, Maidstone, Kent
}

(Accepted for publication 8 February 197I)

\begin{abstract}
SUMMARY
Electron microscopy of ultra-thin sections of the phloem of strawberry plants with green petal disease revealed mycoplasma-like organisms. Similar sections of the phloem of apple trees with chat fruit disease contained similar organisms that differed in size from those in apple with rubbery wood disease. No organisms were found in normal trees of the same varieties.
\end{abstract}

\section{INTRODUCTION}

Because they were graft-transmissible and apparently without bacterial or fungal pathogens, chat fruit and rubbery wood of apple have been regarded as virus diseases. Failure to isolate a specific virus from affected trees was attributed either to low virus concentration or to virus inactivation by tannins or other inhibitors. The discovery of mycoplasma-like organisms in association with several 'virus-like' diseases of plants and their therapy by tetracyclines (Doi, Teranaka, Yora \& Asuyama, 1967; Giannotti, Marchou, Vago \& Duthoit, 1968; Granados, Maramorosch \& Shikata, I968; Lin \& Lee, 1968) prompted a search for Mycoplasmatales in tissues of apple trees infected with chat fruit and rubbery wood diseases.

\section{METHODS}

The material examined included samples of petioles, pedicels, stems, and roots from apple trees infected with chat fruit and rubbery wood diseases (cv. Tydeman's Early and Lord Lambourne respectively) and from healthy trees of the same varieties. For comparison, strawberry plants, cv. Cambridge Favourite, affected by a green petal disease (Posnette, I953) were used as a source of material thought to contain mycoplasma-like bodies for reasons discussed below.

Except where otherwise stated, tissue samples were prepared by glutaraldehyde-osmium tetroxide double fixation, stained with uranyl acetate during dehydration and embedded in Epon 812. The blocks were trimmed on an LKB Pyramitome and sections cut with glass knives on Cambridge (A. F. Huxley pattern) and LKB ultramicrotomes. Some sections were examined immediately in an A.E.I. EM6B electron microscope; others were further stained with lead citrate to emphasize any membrane that might surround organisms found in the sections.

* Present address: Division of Mycology and Plant Pathology, Indian Agricultural Research Institute, New Delhi-I 2, India. 

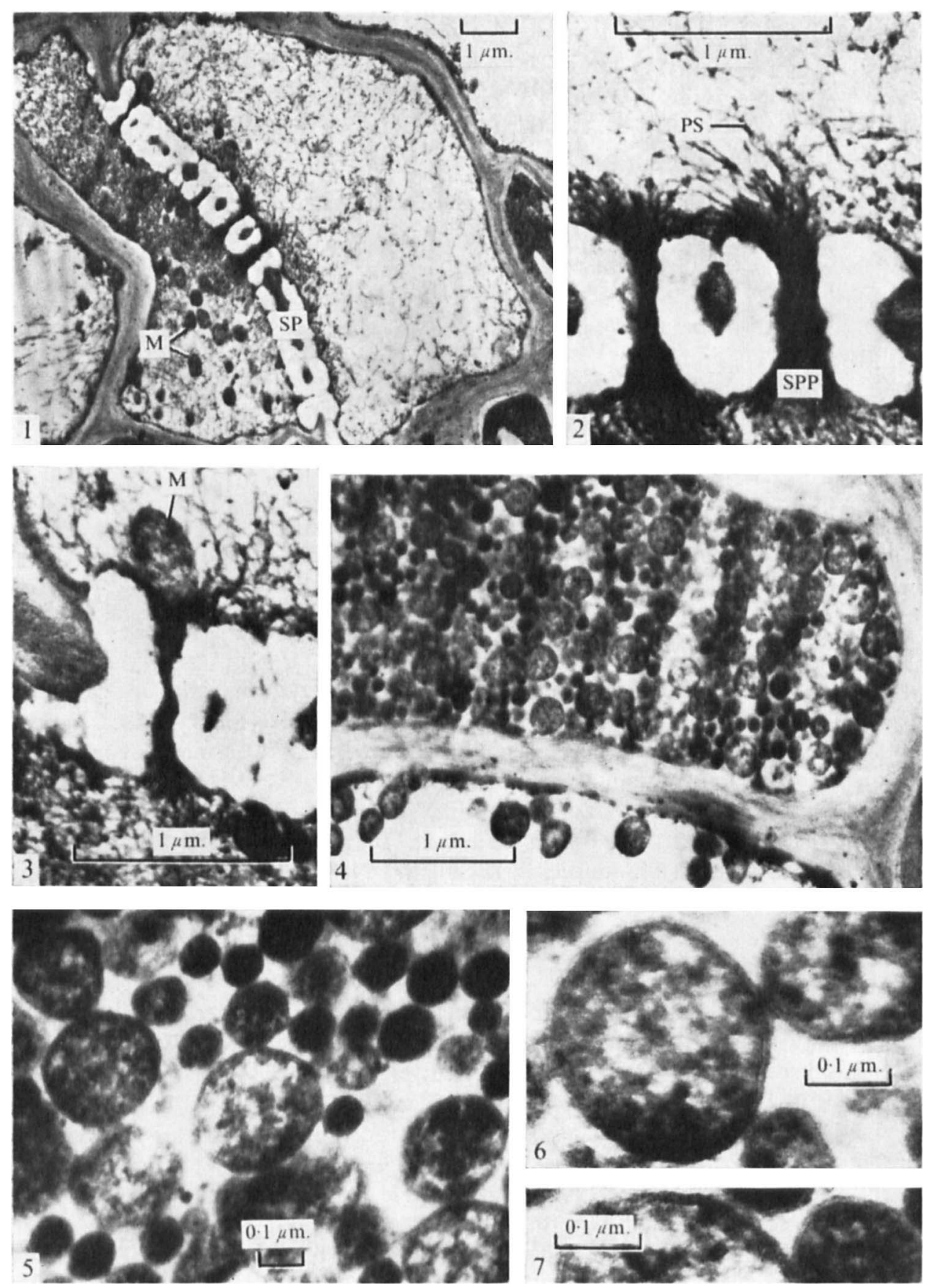

Plate I

Mycoplasmas in ultra-thin sections of phloem from a thalamus of the strawberry variety Cambridge Favourite infected with green petal disease,

Fig. I. Mycoplasmas (M) adjacent to a sieve plate (SP).

Fig. 2. Protein strands (PS) passing through sieve-plate pores (SPP).

Fig. 3. Mycoplasma (M) at the entrance to a sieve-plate pore.

Fig. 4. Phloem cell filled with mycoplasmas of varying sizes, the small electron-dense bodies possibly being elementary bodies.

Fig. 5 to 7. At a higher magnification, the organisms are seen to be enclosed by a trilaminar unit membrane. 

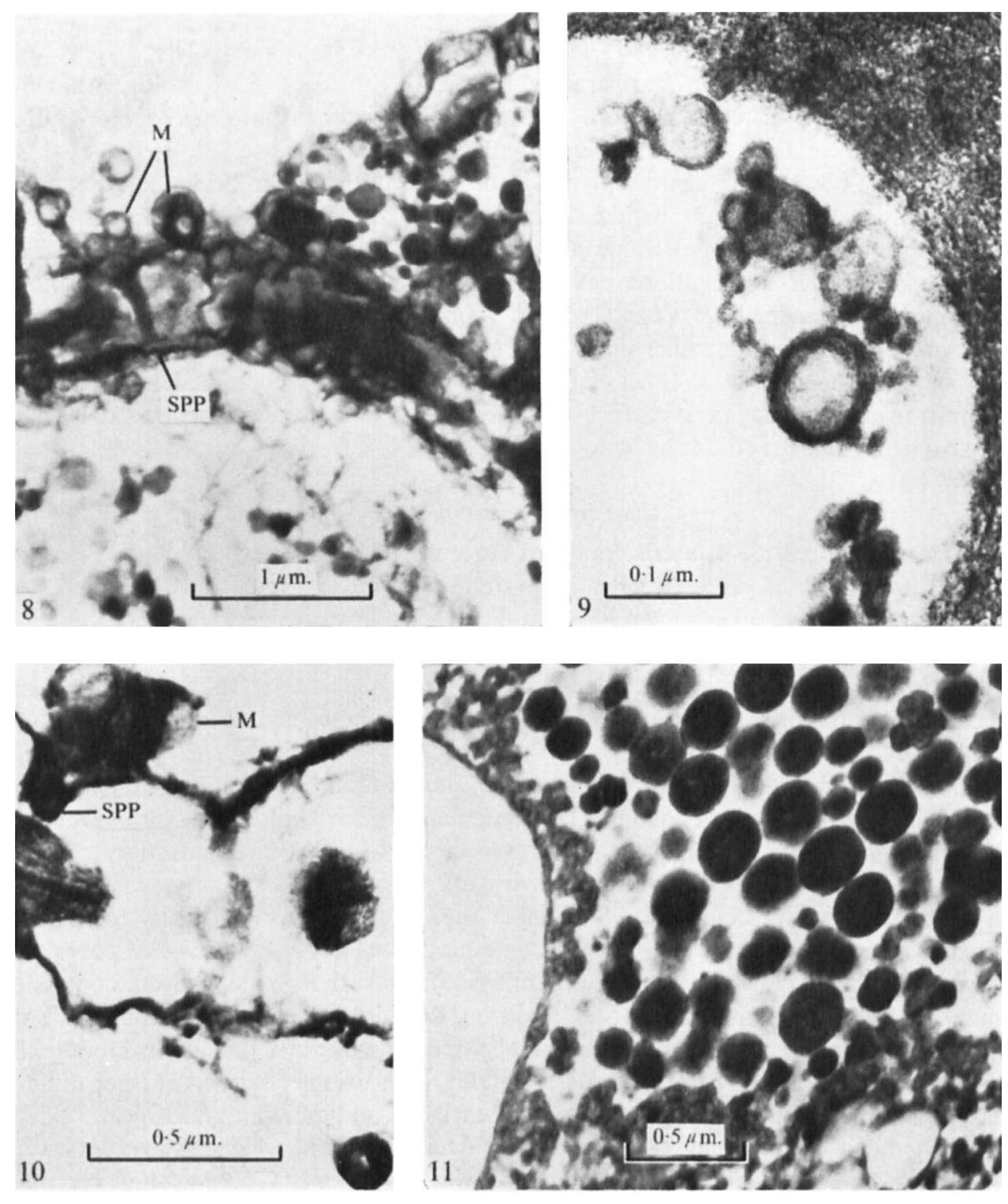

Plate 2

Mycoplasmas in sections of phloem from apple trees infected with chat fruit disease.

Fig. 8, 10. Organisms (M) close to sieve-plate pores (SPP), pedicel, cv. Tydeman's Early.

Fig. 9. A trilaminar unit membrane surrounding the organisms is visible at a higher magnification, pedicel, cv. Tydeman's Early.

Fig. II. Mycoplasmas covering a wide range in size in a portion of a phloem cell that was almost completely filled with such organisms. Stem, cv. Lord Lambourne. 


\section{RESULTS}

\section{Green petal disease of strawberry}

Mycoplasma-like organisms, apparently identical with those associated with clover phyllody (Maillet, Gourret \& Hamon, I968) were numerous in phloem tissue of pedicels and thalamus from the strawberry plants with green petal disease (P1. I, fig. I, 4). No organisms were observed in healthy plants of the same cultivar, Cambridge Favourite. The mycoplasmas were often seen beside sieve plates, as ovoid bodies near the entrance to sieve-plate pores (P1. I, fig. I, 3). Some cells were almost completely filled with mycoplasmas (Pl. I, fig. 4.) Similar aggregations have been observed by other workers: for example, by Giannotti, Devauchelle \& Vago (I968) in Trifolium repens. The closely packed bodies varied greatly in size, the smaller ones being electron-dense and similar to the elementary bodies of other mycoplasmas (Pl. I, fig. 4). The larger bodies contained ribosomes and electron-transparent zones traversed by fine filaments, and they were enclosed by a trilaminar unit membrane (Pl. I, fig. 5 to 7 ).

\section{Chat fruit disease of apple}

Organisms of about the same size range as those observed in strawberry with green petal occurred in sections of pedicels collected in June I969 from Tydeman's Early and Lord Lambourne apple trees affected by chat fruit disease. As in strawberry, the organisms were sometimes congregated alongside sieve plates, especiallyclose to sieve-plate pores (Pl. 2, fig. 8); varying greatly in size, they almost filled some sieve tubes (Pl. 2, fig. I I). Clearly defined trilaminar unit membranes were visible around these organisms in sections poststained with lead citrate (Pl. 2, fig. 9, Io).

Extensive searching failed to reveal any organisms in numerous sections prepared from comparable tissues of healthy plants, i.e. Tydeman's Early and Lord Lambourne trees without chat fruit disease but with the same spectrum of latent virus infection (chlorotic leaf spot, Spy 227 decline and stem-pitting viruses).

In a section of petiole collected in September I 968 from a Tydeman's Early tree severely affected by chat fruit disease, organisms containing one or two nucleus-like zones were observed (P1. 3, fig. I2). These sections were of tissue fixed with formaldehyde and potassium permanganate, stained with uranyl acetate during dehydration, and not post-stained; this method of preparation may account for the apparent absence of a defined membrane, but the organisms also differed from those described above in being composed of three different parts, viz. an outer, rather electron-transparent envelope and an inner, more electron-dense zone (Pl. 3, fig. 13) containing one or two very dense bodies in which a substructure was visible ( $\mathrm{Pl}$. 3, fig. I4 to $\mathrm{I} 7$ ). The outer envelope, which was only visible around certain of the larger bodies, may have represented a capsule, or slime layer.

\section{Rubbery wood disease of apple}

Organisms about six times larger than those associated with chat fruit disease were observed in sections of Lord Lambourne apple affected by rubbery wood disease and not by chat fruit ( $\mathrm{Pl}$. 4, fig. 18 to 20 ). Several bodies adjacent to a phloem cell wall are shown in Pl. 4, fig. I 8. These bodies were frequently filled with ribosomes (P1. 4, fig. I9 to 2I). The protrusion on a body illustrated in $\mathrm{Pl} .4$, fig. 20, may be the base of a filament outside the plane of sectioning. 

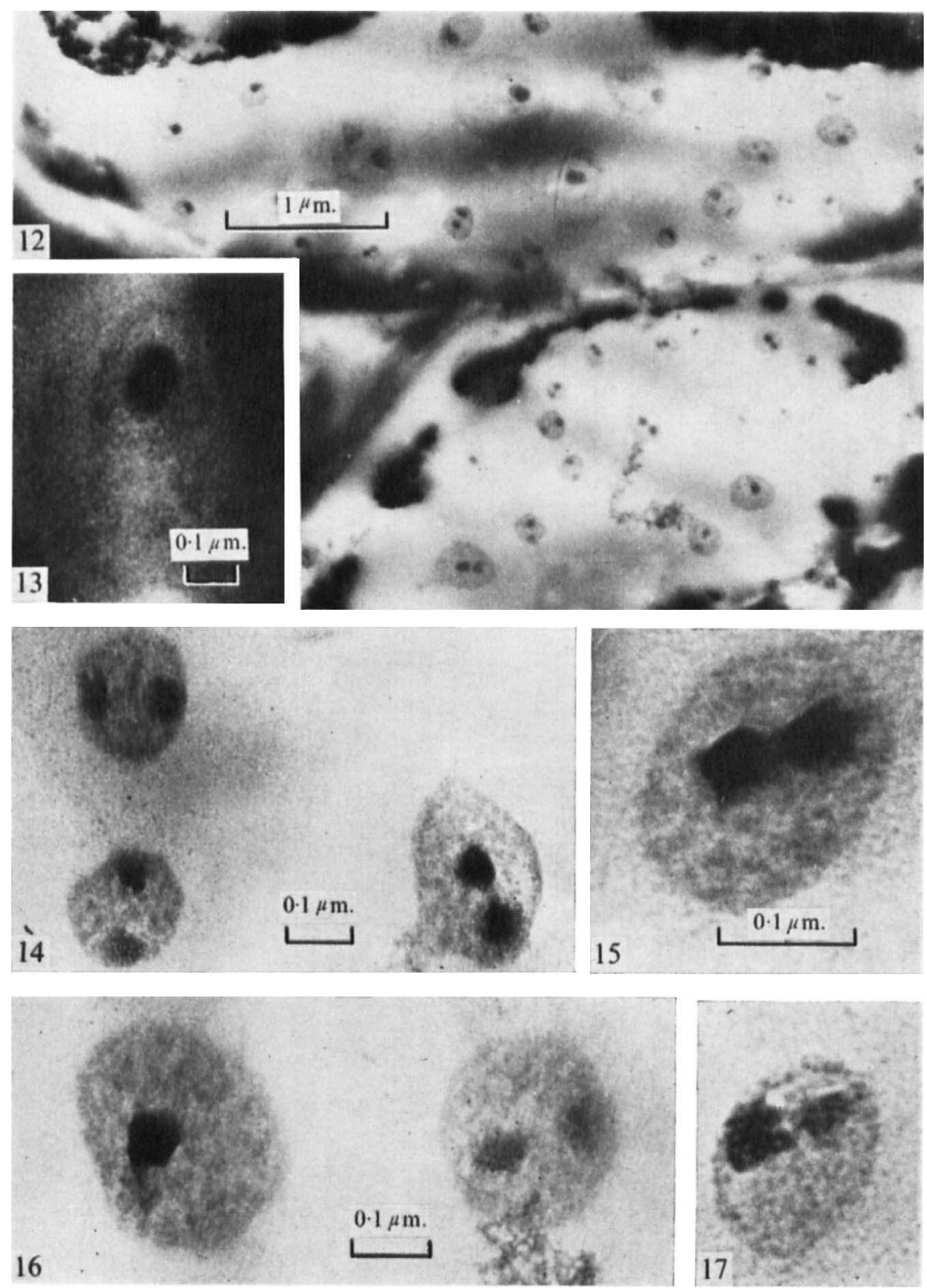

Plate 3

Organisms with nucleus-like zones in a section of phloem tissue from an apple petiole, cv. Tydeman's Early infected with chat fruit disease.

Fig. 12. A pair of dense bodies are present in many of the organisms.

Fig. 13. A single organism showing an outer, rather electron-transparent envelope and an inner, more electron-dense zone with a dense inclusion.

Fig. I4 to 17. At a higher magnification a substructure is visible in the dense zones near the centres of the organisms. Fig. 17 is at the same magnification as Fig. 15. 

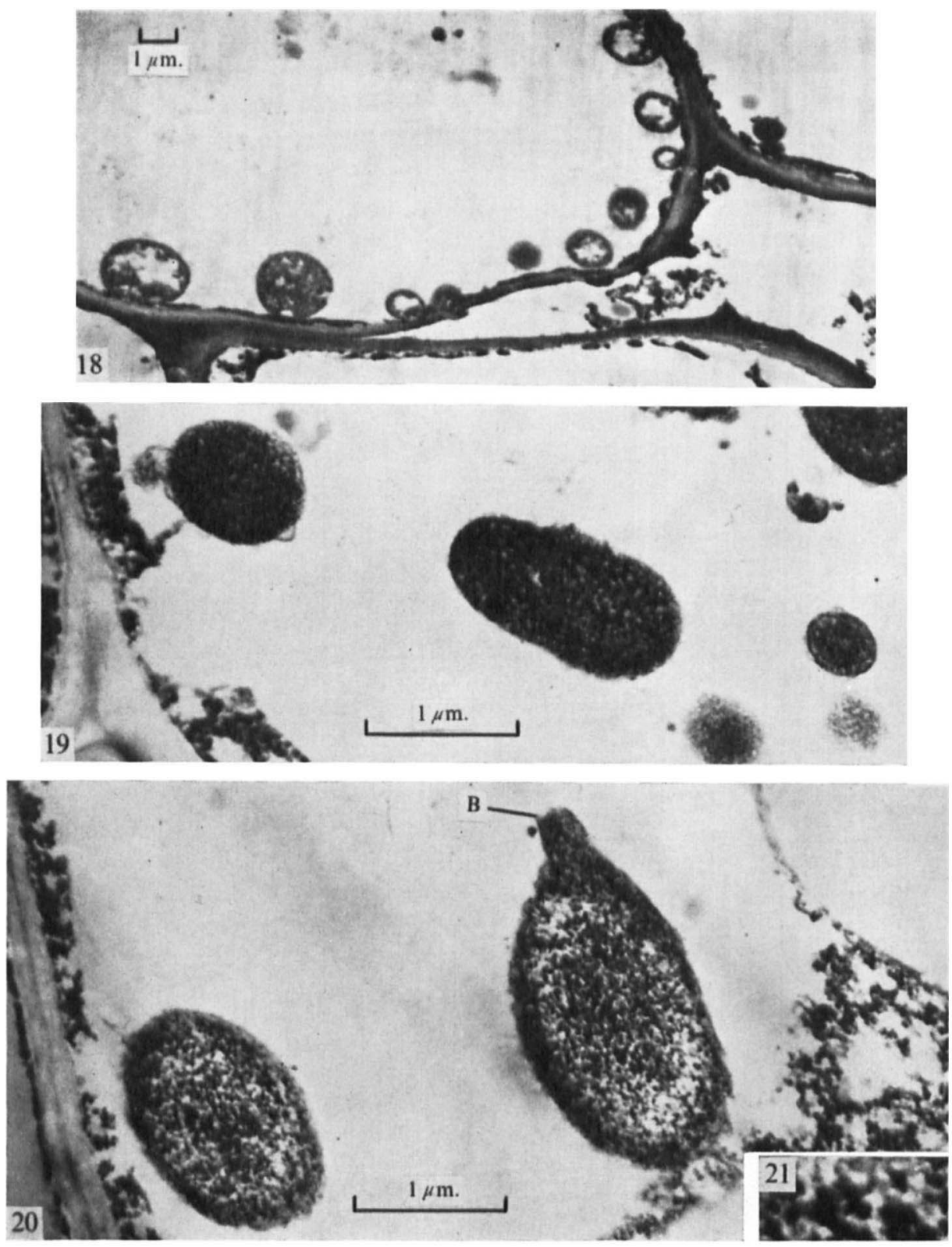

\section{Plate 4}

Large mycoplasmas in sections from an apple tree infected with rubbery wood disease. The composite tree consisted of the scion variety Lord Lambourne on the rootstock Malling 26.

Fig. 18. Organisms in a phloem cell from a root.

Fig. 19, 20. Densely stained organisms in stem sections. The base of a filament (B) is present.

Fig. 2I. At three and a half times the magnification of fig. 20 ribosomes are visible. 


\section{DISCUSSION}

Apple trees with chat fruit and rubbery wood diseases contained organisms that were not found in intensive studies of sections of normal trees of the same cultivars. Though many more sections of normal than of diseased apple trees were examined, it cannot be claimed that these organisms never occur in normal trees. The organisms in trees affected by each of these two diseases were different from each other and also from those associated with green petal disease of strawberry. This disease was used for comparison because the causal agent, the same as that responsible for clover phyllody (Frazier \& Posnette, 1957), was already known to be mycoplasma-like (Maillet, et al. I968).

The only disease of apple previously associated with mycoplasma-like bodies is proliferation (Giannotti, Morvan \& Vago, I968); this disease resembles chat fruit in that the agent responsible is not fully systemic, i.e. a high proportion of scion buds from affected trees was not infected in tests for transmission and perpetuation by grafting (Bovey, I963; Posnette \& Cropley, 1965).

Chat fruit and apple proliferation diseases also have in common the symptom of diminished fruit size. They differ, however, in that trees with proliferation disease tend to recover almost to normal (Bovey, I963), whereas chat fruit causes a progressive reduction in size of fruit (Posnette \& Cropley, 1965) and does not induce the proliferation or witches' broom effect characteristic of the proliferation disease.

Organisms of rather similar structure and of the same order of size as those in Tydeman's Early, illustrated in Pl. 3 of the present paper, were observed by Gourlay \& Thrower (1968), in Mycoplasma mycoides. Those illustrated in Pl. 3, fig. 9, of Gourlay \& Thrower's paper are, for example, enclosed in a capsule and they contain a pair of inclusions differing in electron density from the rest of the cell. The structure of the granular material around mycoplasma cells, shown in fig. 8 in the plate of Gourlay \& Thrower's paper, closely resembles that of the wisps of granular material beside certain of the organisms in Tydeman's Early apple (Pl. 3, fig. I 2 and 14 ). The dense bodies within the organisms observed in the present work bear a resemblance - especially as regards their substructure - to those present in certain protozoa (Arvy \& Franc, 1968), though, of course, the size of the protozoa and of their inclusions is many times greater. Nevertheless, certain affinities do exist between mycoplasmas and protozoa especially in their sterol requirements, in the absence of a rigid cell wall (Edward \& Freundt, I969) and possibly also in certain aspects of their internal structure.

Rubbery wood disease is caused by an agent that differs from those responsible for chat fruit and proliferation disease in being present in most individual buds which are sufficiently developed to be used as graft-inoculum (Posnette \& Cropley, I954). However, two features are compatible with a non-virus aetiology: (I) ease of heat inactivation; the agent is more readily inactivated by maintaining plants at $36^{\circ}$ than are most other apple pathogens thought to be viruses (Posnette, Cropley \& Wolfswinkel, 1962; Campbell, I968); (2) trees free from rubbery wood were propagated by culturing sphaeroblasts excised from affected trees (R. Garner \& R. Cropley, personal communication). As sphaeroblasts are known to be initiated in the cortex and without connexion with existing phloem tissue (Baldini \& Mosse, I956), their development into rubbery wood-free trees suggests that the causal agent of this disease may be restricted to the vascular system.

The authors wish to acknowledge the assistance of Dr R. C. Hignett, Dr R. Cropley and Miss W. Manwell in the preparation of many of the tissue samples, and of Miss M. M. Fuller in electron microscopy. 


\section{REFERENCES}

ARVY, L. \& Franc, A. (1968). Sur un protiste nouveau, agent de destruction des branchies et des palpes de l'Huître Portugaise. Compte rendu hebdomadaire des séances de l'Académie des sciences, Paris Serie D, 267, $103-105$.

BaldiNI, E. \& Mosse, B. (1956). Observations on the origin and development of sphaeroblasts in the apple. Journal of Horticultural Science 3r, I56-162.

Bovey, R. (1963). Observations and experiments in apple proliferation disease. Phytopathologia Mediterranea 2, III-II3.

CAMpbell, A. I. (1968). Heat sensitivity of some apple viruses. Tagungsberichte Deutsche Akademie der Landwirtschaftswissenschaften zu Berlin 97, 3 I I-31 5 .

Doi, Y., Teranaka, M., Yora, K. \& AsuYama, H. (1967). Mycoplasma- or PLT group-like micro-organisms found in the phloem elements of plants infected with Mulberry Dwarf, Potato Witches' Broom, Aster Yellows, or Paulownia Witches' Broom. Annals of the Phytopathological Society of Japan 33, $259-266$.

Edward, D. G. FF. \& Freundt, E. A. (1969). The Mycoplasmatales and the L-phase of Bacteria, p. 153. Edited by L. Hayflick. Amsterdam: North-Holland Publ. Co.

Frazier, N. W. \& Posnette, A. F. (I957). Transmission and host-range studies of strawberry green-petal virus. Annals of Applied Biology 45, 580-588.

Giannotti, J., Devauchelle, G. \& Vago, C. (I968). Micro-organismes de type mycoplasme chez une cicadelle et une plante infectées par la phyllodie. Compte rendu hebdomadaire des séances de l'Académie des sciences, Paris Serie D, 266, 2 I68-2170.

Giannotti, J., Marchou, G., Vago, C. \& Duthoit, J.-L. (1968). Micro-organismes de type mycoplasme dans les cellules libériennes de Solanum lycopersicum $\mathrm{L}$. atteinte de Stolbur. Compte rendu hebdomadaire des séances de l'Académie des sciences, Paris Serie D, 267, 454-456.

Giannotti, J., Morvan, G. \& Vago, C. (I968). Micro-organismes de type mycoplasme dans les cellules libériennes de Malus sylvestris L. atteinte de la maladie des proliferations. Compte rendu hebdomadaire des séances de l'Academie des sciences, Paris Serie D, 267, 76-77.

Gourlay, R. N. \& Thrower, K. J. (1968). Morphology of Mycoplasma mycoides thread-phase growth. Journal of General Microbiology 54, I55-159.

Granados, R. R., Maramorosch, K. \& Shikata, E. (1968). Mycoplasma: suspected etiologic agent of corn stunt. Proceedings of the National Academy of Sciences of the United States of America 60, 84I-844.

LIN, S.-C. \& LEE, C.-S. (I968). Mycoplasma or mycoplasma-like micro-organisms in white leaf disease of sugar cane. Report of the Taiwan Sugar Experiment Station, 1967-1968, p. 17-19.

Maillet, P. L., Gourret, J.-P. \& Hamon, C. (I968). Sur la présence de particules de type mycoplasme dans le liber de plantes atteintes de maladies du type 'jaunisse' (Aster Yellow, Phyllodie du Trèfle, Stolbur de la Tomate) et sur la parenté ultrastructurale de ees particules avec celles trouvées chez divers insectes homoptères. Compte rendu hebdomadaire des séances de l'Académie des sciences, Paris Serie D 266, 2309-23II.

Posnette, A. F. (1953). Green petal - a new virus disease of strawberries. Plant Pathology 2, I7-18.

Posnette, A. F. \& Cropley, R. (1954). Distribution of rubbery wood virus in apple varieties and rootstocks. Report of East Malling Research Station for 1953, pp. 150-153.

Posnette, A. F. \& Cropley, R. (1965). Field experiments with chat-fruit virus disease of apple. Annals of Applied Biology 55, 439-445.

Posnette, A. F., Cropley, R. \& Wolfswinkel, L. D. (1962). Heat inactivation of some apple and pear viruses. Report of East Malling Research Station for 1961, pp. 94-96. 